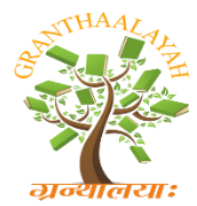

$$
\begin{aligned}
& \text { INTERNATIONAL JOURNAL OF RE } \\
& \text { GRANTHAALAYAH } \\
& \text { A knowledge Repository }
\end{aligned}
$$

Management

\title{
MANAGEMENT OF PONDOK PESANTREN ENTREPRENEURSHIP IN EMPOWERMENT OF COMMUNITY ECONOMY IN RIAU PROVINCE
}

\author{
Ahmad Syukri ${ }^{1}$, Kasful Anwar Us ${ }^{2}$, Fahrina Yustiasari Liriwati ${ }^{3}$ \\ ${ }^{1,2}$ Postgraduate Lecturer UIN Sulthan Thaha Saifuddin Jambi \\ ${ }^{3}$ Lecturer STAI Auliaurrasyidin Tembilahan
}

\begin{abstract}
The research approach used is a qualitative approach, it is hoped that the lifting of the picture of quality, social reality and perceptions of the target researchers. Information obtained through purposive sampling based on research needs. The research subjects consisted of three leaders of Islamic boarding schools (Islamic Boarding School Chairman Khairul Ummah, Indragiri Hulu Regency, Islamic Boarding School Al-Amin Dumai Boarding Schools, and Boarding School AlMujtahadah Islamic Boarding School Pekanbaru). Data collection techniques carried out by observation, interview and documentation.

The results of entrepreneurship management research in Islamic boarding schools in empowering the economic community is managerially, the three boarding schools delegate their entrepreneurial management to people appointed by the head of the boarding school. In addition, they create a specific agency, field or work unit to take care of existing entrepreneurship.

The Community Economic Empowerment Model conducted by the three Islamic boarding schools in Riau province, namely the Khairul Ummah Islamic boarding school, chose the laundry business unit as a medium for community economic empowerment. This laundry business unit is an Islamic boarding school based women's empowerment activity with the name of the mother laundry group, Al-Amin Dumai Islamic boarding school conducting community economic empowerment activities in the field of oyster mushroom cultivation and training and processing of oyster mushroom cultivation products while the model of community economic empowerment is carried out in Islamic boarding schools Al-Mujtahadah Pekanbaru through learning life skills in the form of automotive training at the Al-Mujtahadah Islamic Boarding School Work Training Community in Pekanbaru.

The contribution of entrepreneurship management in Islamic boarding schools in Riau province in community economic empowerment lies in two aspects, namely the material aspect and the moral aspect, in the material aspect namely; 1. operational funding for institutions and boarding schools, 2. construction and maintenance of infrastructure for boarding schools, 3 . welfare of students and community life. While on the moral aspect, namely; 1 . provide entrepreneurial experience to the students, 2. learning for students and the community to entrepreneurship, 3. a harmonious relationship between the boarding school and the community, 4. be an example of a communitybased boarding school entrepreneurship.
\end{abstract}

Keywords: Management; Entrepreneurship; Community Empowerment. 
Cite This Article: Ahmad Syukri, Kasful Anwar Us, and Fahrina Yustiasari Liriwati. (2020). "MANAGEMENT OF PONDOK PESANTREN ENTREPRENEURSHIP IN EMPOWERMENT OF COMMUNITY ECONOMY IN RIAU PROVINCE." International Journal of Research - Granthaalayah, 8(3), 136-146. https://doi.org/10.29121/granthaalayah.v8.i3.2020.138.

\section{Introduction}

Pesantren as an Islamic education institution that is pro-people or pro-community should empower the community not only in terms of ukhrawi (spiritual) but also worldly things such as entrepreneurship, agribusiness, community-based pesantren and others. In Riau Province itself, there are still relatively few entrepreneurship-based pesantren that empower the community in streamlining their entrepreneurship curriculum, such as those found in several boarding schools in Riau Province.

Based on the results of the grand tour conducted by researchers in Islamic boarding schools in Riau Province, namely in the Khairul Ummah Islamic Boarding School, Indragiri Hulu Regency, Al-Amin Dumai Islamic Boarding School, and Al-Mujtahadah Islamic Boarding School in Pekanbaru, there are many advantages that can be observed from observations and interviews. researchers do as follows:

First, the Khairul Ummah Islamic Boarding School is located on Jalan Jendral Sudirman, Batu Gajah Air Molek Village, Pasir Penyu District, Indragiri Hulu Regency, Riau Province. This boarding school was established on July 17, 1995 under the Indragiri Islamic Foundation (YASIIN), which was founded by Alm.KH. Munashir Jufri, and became the leader of the cottage from 1995 to 2005. Furthermore, from 2005 until now it is led by KH. Muhammad Mursyid, M.Pd.I.

Based on the results of preliminary observations researchers do look that the boarding school Khairul Ummah Indragiri Hulu is also an entrepreneurial boarding school. Khairul Ummah Islamic Boarding School has several business units, namely: having 120 trees of aloes wood, 20 hectares of oil palm plantations, 30 ponds of catfish ponds with 9,000 catfish seedlings, and boarding school cooperatives. In addition, the boarding school partnered with local tailors to procure 600 santri uniforms each year. Laundry Business Unit of Islamic boarding school involving mothers around the pesantren.

Based on the results of interviews with the leaders of the boarding school KH. Muhammad Mursyid, M.Pd.I one form of business that directly involves the community is a laundry business of 67 laundry mothers with an income of 1.5 million - 2 million per month. This Loundry business has been carried out since 2010 on the grounds that the increasing number of santri is 1,526 people, which certainly requires a lot of water in terms of washing clothes. Therefore, the Khairul Ummah Islamic boarding school makes this a business opportunity to partner with the local community.

Secondly, Al-Amin Islamic Boarding School in Dumai, from the results of preliminary observations by researchers in the field, it is seen that the Al-Amin Islamic Boarding School in Dumai is under the leadership of Kyai Zainal Abidin, S.Pd.I, which was established in 2004. Located on Jalan Prof. M. Yamin Bagan Keladi Barat Dumai, Riau Province is an entrepreneur- 
based boarding school and is an entrepreneurship training center for every boarding school in Riau Province.

Third, based on the grand tour of researchers at the Al-Mujtahadah Islamic Boarding School in Pekanbaru under the leadership of Prof. Dr. H. Mujahiddin, MA who is also the number one person at UIN Sultan Syarif Kasim Riau. In its development the Al-Mujtahadah Islamic boarding school developed a program of printing scholars who have the qualifications of the Qur'an hafiz, mastering the yellow book and mastering Arabic and English well. Al-Mujtahadah Islamic Boarding School stands on a land of $12,500 \mathrm{M} 2$ and is also an entrepreneur-based Islamic boarding school.

Al-Mujtahadah Islamic Boarding School is a community vocational training center (BLK) in the automotive sector in Riau province and has a work hall training center that takes turns taking students from the Vocational High School of Riau province for apprenticeships and automotive training in collaboration with the Provincial Vocational Training Center Riau Al-Mujtahadah Islamic Boarding School also has a 2-hectare guava honey and soursop plantation and management of a boarding school cooperative.

The world of entrepreneurship is one aspect that can help to survive in this era. It is a necessity if all parties explore anything that can help prepare superior resources in the world of entrepreneurship. One of them is pesantren educational institutions in improving the economic conditions of the surrounding community. Therefore, this research is important to do.

\section{Theoretical Basis}

\subsection{Entrepreneurship Management in Pondok Pesantren}

Management can be simplified into four basic functions, namely planning, organizing, implementation and supervision. Management is a process or framework that involves planning, organizing and monitoring processes so that the implementation of a planned business is systematic and can be evaluated properly, accurately, and completely so as to achieve goals productively, quality, effectively and efficiently.

Entrepreneurship is the equivalent of entrepreneurship in English, unternehmer in German, ondernemen in Dutch. Whereas in the Indonesian language with the name of entrepreneurship. The word Entrepreneur comes from French, entreprendre which means adventurer, risk taker, contractor, entrepreneur and creator who sells his creations. Entrepreneurial management is the utilization of economic potential in a creative, innovative and with the courage to face the risk of getting useful profits to the success of programs in an organization.

Islamic Boarding School as an educational institution that is still steadfast and consistently performs its role as a center for the deepening of the religious sciences (tafaqquh fi al-din) and Islamic propaganda institutions and participates in educating the nation has been recognized by the community, evidenced by its success in printing religious figures, nation fighters and community leaders, both in the pre-independence era, after independence and today. This is clear 
evidence that Islamic boarding schools have contributed a lot in building the Indonesian nation, including in the field of entrepreneurship.

Actually, in Islam we are required to be entrepreneurs, because by developing this entrepreneur can be able to make people who are independent in the field of income without relying on others, and to become an entrepreneur is certainly not as easy as turning the palm of the hand, it requires continuous process and learning and demanded to be a person who think creatively and innovatively and work hard.

\subsection{Community Economic Empowerment}

Empowerment according to language comes from the word power which means power / strength, process, method, act of empowering. Empowerment is an effort to build community power by encouraging, motivating and raising awareness of their potential and striving to develop them.

Community empowerment is an effort to make people independent, through the realization of the potential abilities they have. The concept of empowerment can be seen from three sides namely; First, empowerment by creating a developing atmosphere or climate. Second, empowerment to strengthen the economic potential or power of the community. In order to strengthen this potential, very basic efforts are to improve the level of education, health status and access to sources of economic progress, such as capital, technology, information, employment and markets. Third, empowerment through the development of the people's economy by protecting and preventing unbalanced competition and creating togetherness and partnerships between the advanced and the undeveloped.

Community Empowerment in essence has two main meanings, namely: 1) increasing the ability of the community (to give ability or enable) through the implementation of various development policies and programs so that the living conditions of the community can reach the level of ability expected, and 2) increasing community independence through granting authority proportionately to the community in making decisions (to give authority) in order to develop themselves and their environment independently. This shows that the effort of community empowerment means enabling and independence of the community.

Based on the theory above, that to empower the community's economy requires a long process, through several stages of activities that are sustainable. Some stages of the activity include; apprenticeship training, proposal preparation, capital, assistance, business networking and so on.

Likewise, boarding schools that want to succeed in developing their activities in the context of economic empowerment of their communities, the boarding schools need to arrange some coaching programs that can be carried out through several stages of activities as mentioned above. The program can be implemented through activities that are sustainable.

\section{Research Methodology}

Research on Entrepreneurship Management in Islamic Boarding Schools in community economic empowerment in Riau province uses a qualitative approach. Creswel defines qualitative research 
in the form of methods to explore and understand the meaning ascribed to social problems by involving important efforts such as asking questions and procedures for collecting specific data from participants. Research approaches are structured, planned and procedural ways to conduct a scientific research by combining all the potential and resources that have been prepared. The research approach is very much determined by the research paradigm, which is a perspective chosen by the researcher.

\section{Findings and Analysis}

The role of pesantren in general community empowerment is as follows; As an educational institution that has an Islamic style, pesantren is the center of Islamic mental and spiritual development. Religious values implemented by pesantren have great potential to change human resources and the surrounding community from passive society to proactive community. The scientific tradition of the pesantren has an important role in the effort to advance a society. Those who are knowledgeable are guiding the community towards the ideals which are the common goal, namely the welfare of life.

The spirit of social solidarity and shared life owned by pesantren is a moral foundation to develop the community through cooperation between the government and pesantren to drive the economy of the community around the pesantren. Quality human resources determines the progress of pesantren in the future. The higher the quality of education in pesantren, the higher the quality of people who believe in and fear Allah SWT, in essence this situation can affect the improvement of people's welfare.

Islamic boarding schools are historical products that have had dialogues with their respective times which have different characteristics, both socio-political, socio-cultural, socio-economic and socio-religious. Islamic boarding school is one of the forerunners and pillars of education in Indonesia, in addition to general education and madrasa. Pesantren is an educational institution that has proven to play an important role in transmitting religious sciences in society.

The Riau Provincial Government is very intense in paying attention to Islamic boarding schools in Riau province whose growth is so rapid that currently there are 218 boarding schools spread across 12 districts / cities. In the modern era, there are many different systems that are used to promote Islamic boarding schools, there are those that prioritize Arabic and English into superior programs and there are also making the Al-Qur'an's tahfizh program a superior program.

Pesantren as a form of traditional Islamic education because pesantren as an educational institution that upholds and preserves the traditions, culture, order of Islamic life in the educational process to its students. The general pattern of pesantren education is as follows: 1) close relationship between the kiyai and santri, 2) the tradition of submission and compliance of a santri to kiyai, 3) a simple lifestyle (zuhud), 4). Independence, 5). developing a tradition of help and help and a brotherly atmosphere, 6). strict discipline, 7.) dare to suffer to achieve goals and 8). life with a high degree of religiosity.

Pesantren is a living social institution that has strong potential as a driving force in community economic empowerment. Community Economic Empowerment Model conducted by Islamic 
Boarding Schools in Riau Province (Study at Khairul Ummah Islamic Boarding School in Indragiri Hulu Regency, Al-Amin Dumai Boarding Schools and Al-Mujtahadah Islamic Boarding Schools in Pekanbaru) namely; Khairul Ummah Islamic boarding school, chose the laundry business as a medium for community economic development and empowerment.

Laundry business activities are women's empowerment activities based on Islamic boarding schools. The pesantren-based women's empowerment model is named the Laundry Laundry Business Group. While the Al-Amin Dumai Islamic boarding school conducts community economic empowerment activities in the field of oyster mushroom cultivation and processed training for oyster mushroom cultivation products, and the community economic empowerment model conducted by the Al-Mujtahadah Islamic boarding school in Pekanbaru. through life skills learning in the form of automotive training at the Vocational Training Center (BLK) at the AlMujtahadah Islamic boarding school in Pekanbaru - Riau.

Contribution of Entrepreneurship Management in Islamic Boarding Schools in Riau Province (Study in Islamic boarding school Khairul Ummah, Indragiri Hulu Regency, Al-Mujtahadah Islamic Boarding School in Pekanbaru, Al-Amin Dumai boarding school) in Community Economic Empowerment are on 2 aspects, namely material and moral aspects, on aspects of the Al-Mujtahadah Islamic boarding school in Pekanbaru, Al-Amin Dumai boarding schools) in Community Economic Empowerment material namely; a. Funding for operational institutions and boarding schools, b. construction and maintenance of facilities for boarding schools, c. welfare of students and community life. All three are the result of material contributions given by business units managed by Islamic boarding schools. While on the moral aspects namely; a. Give more experience to the students, b. Learning for students and the community for entrepreneurship, c. Harmonious relationship between Islamic boarding school and the community, d. An example of a community-based boarding school entrepreneurship.

\section{Conclusions, Theory and Practical Implications}

The results of the research and discussion on Entrepreneurship Management of Islamic Boarding Schools in the economic empowerment of the people in Riau Province (Study at the Khairul Ummah Islamic Boarding School in Indragiri Hulu Regency, Al-Amin Dumai Boarding Schools and Al-Mujtahadah Islamic Boarding Schools in Pekanbaru,) can be summarized as follows.

Entrepreneurship Management in Islamic boarding schools in Khairul Ummah Islamic Boarding Schools in Indragiri Hulu Regency, Al-Amin Dumai boarding schools and Al-Mujtahadah Islamic boarding schools in Pekanbaru, Riau province, operate similar management patterns. The clerics in these three Islamic boarding schools delegate some of their authority to those appointed and given the authority to manage business units under the boarding school. The difference lies only in the business units run by each boarding school.

This research provides theoretical implications, namely strengthening and perfecting the theory of GR theory Terry said that 'management is a typical process consisting of planning, organizing, mobilizing, and controlling actions to determine and achieve goals through the use of human resources and other sources, and Peter Van Der Sijde's theory that entrepreneurship is something a person learns when that person runs it. Whereas Khan offers an empowerment model that can be 
developed in an organization to ensure the success of the empowerment process, namely: 1). Desire (delegation), 2). Trust 3). Confident 4). Credibility, 5). Accountability (responsibility), 6). Communication

From the conceptualization framework of the theory above, the entrepreneurship management of Islamic boarding schools in community economic empowerment must make significant changes, both in terms of human resources, managerial systems, and optimizing the role of technology in its implementation. The empirical findings in the field as explained in the previous discussion mentioned that the Khairul Ummah boarding school, Al-Amin Dumai boarding school and AlMujtahadah boarding school Pekanbaru, namely;

first; have a detailed concept of entrepreneurship management in a boarding school that starts from the planning process in the form of vision, mission, programs and targets to be achieved, second: The boarding school leadership delegates some of the authority of the clerics to people who have adequate background knowledge and abilities in the field of entrepreneurship, third: Islamic boarding school Khairul Ummah, Islamic boarding school Al-Amin and Islamic boarding school Al-Mujtahadah Pekanbaru have very good business units, fourth: Based on the supervision system, Islamic boarding school Khairul Ummah, Islamic boarding school Al-Amin and Islamic boarding school Al- Mujtahadah Pekanbaru has a pretty good supervision system. Fifth: business units developed in three Islamic boarding schools contribute positively to the economic empowerment of the community.

Entrepreneurship management of Islamic boarding schools in the economic empowerment of communities in Riau province can be improved with more support from the local government and support from the private sector. This will greatly support the progress of the process of community economic empowerment.

With this support, the boarding school will be more enthusiastic in carrying out entrepreneurial activities in community economic empowerment. This entrepreneurial activity will be very beneficial for boarding schools and the community because it provides a symbiotic relationship of mutualism for both parties. Islamic boarding schools are increasingly developing their entrepreneurial activities and society is increasingly increasing its economic well-being.

\section{References}

[1] Al-Qur"an dan Terjemahnya, Jakarta: Lautan Lestari, 2010

[2] Abudin Nata, Pendidikan dalam Perspektif Al-Qur'an, J a k a r t a : Kencana, 2016

[3] Abi Abdillah Muhammad ibn Ismail al-Bukhori, Matan Al-Bukhori Masykul: Bihasyiyah al-Sindi, juz.2, Beirut: Dar al-Fikr, tt

[4] Abdullah Syukri Zarkasyi, Gontor dan Pembaharuan Pendidikan Pesantren, Jakarta: Raja Grafindo Persada, 2005

[5] Abdullah Idi, Sosiologi Penduduk; Individu, Masyarakat dan Pendidik, Jakarta: Rajawali Press, 2011

[6] Abdul Halim Usman, Manajemen Strategis Syariah, Jakarta: Zikrul Hakim, 2015

[7] Abdul Mue in, Pesantren dan Pengembangan Ekonomi Pondok Pesantren Jakarta: Prasasti, 2015

[8] Abu, Ala, Peran Pesantren Dalam Transformasi Sosial, dalam Pembaruan Pesantren, Yogyakarta: LKIS Printing, 2016 
[9] Abdul Rahmat dan Sriharini, Manajemen Profetik; Model Pemberdayaan Masyarakat Berbasis Pesantren Alam Gorontalo: Ideas Publishing, 2018

[10] Achmad Toto Purnomo dan Djoko Agus Purwanto, Pelatihan Budidaya Jamur Tiram Sebagai Program Pemberdayaan Santri Di Pesantren Annur Fatmah, Desa Belim Kabupaten Mojokerto, Jurnal Layanan Masyarakat, Vol.1(1): 10 - 20

[11] Ahmad Suharto, Profil Pondok Pesantren Modern Gontor, Ponorogo: Darussalam Press, 2011

[12] Ali Anwar, Pembaruan Pendidikan di Pesantren Lirboyo Kediri. Yogyakarta: Pustaka Setia, 2011

[13] Ahmad Mutohar dan Nurul Anam, Manifesto Modernisasi Pendidikan Islam dan Pesantren, Yogyakarta: Pustaka Pelajar, 2013

[14] Agus Siswanto, The Power of Islamic Entrepreneurship: Energi Kewirausahaan Islami, Jakarta: Amzah, 2016

[15] Alam terkembang dan Sugiarti, Cahaya Dilangit Pesantren, Indragiri Hulu: Pondok pesantren Khairul Ummah, 2015

[16] Amir Hamzah Wirosukarto, et.al. KH.Imam Zarkasyi Dari Gontor Merintis Pesantren Modern, Ponorogo: Gontor Press, 2011

[17] Amin Hadari, Masa Depan Pesantren; Dalam Tantangan Modernitas Dan Tantangan Kompleksitas Global, Jakarta: IRD Press, 2004

[18] Anggadwita dan Dhewanto, Women's Entrepreneurial Intentions In Micro And Small Enterprices In Indonesia, journal of administrative and business studies, 2015

[19] Aprillia Theresia dkk, Pembangunan Berbasis Masyarakat, Bandung: Alfabeta, 2015

[20] A.Halim dkk, Manajemen Pesantren, Yogyakarta : LKis Yogyakarta, 2005

[21] A.Malik, Inovasi Kurikulum Bebasis Lokal di Pesantren, Jakarta: Balai Penelitian dan Pengembangan Agama, 2008

[22] Aziz Muslim, Metodologi Pengembangan Masyarakat, Yogyakarta: Teras, 2010

[23] Aziz Muslim, Dasar-Dasar Pengembangan Masyarakat, Yogyakarta: Samudera Biru, 2012

[24] Baddrut Tamam, Pesantren Nalar Dan Tradisi, Yogyakarta: Pustaka Pelajar, 2015

[25] Badrudin, Dasar-dasar Manajemen. Bandung: Alfabeta, 2017

[26] Buchari Alma, Kewirausahaan. Bandung: Alfabeta, 2017

[27] Buku Panduan Penulisan Tesis dan Disertasi, Pasca Sarjana IAIN Sulthan Thaha Saifuddin Jambi, Tahun 2017

[28] Creswell, Jhon W. Terjemahan Achmad Fawaid, Research Design Pendekatan Kualitatif, Kuantitatif dan Mixed, Yogyakarta: Pustaka Pelajar, 2014

[29] Cory Gardenhour, Teacher's perceptions of Empowerment in their work environment as measured by the pscychological empowerment Instrument, Disertasi, Tahun 2008, Universitas Negeri Tennesse Timur.

[30] Darsono Prawironegoro, Kewirausahaan Abad 21, Jakarta: Mitra Wacana Media, 2017

[31] Dimeck, The Excuite in action, New York: Harpen and Bross, 1954

[32] Edi Suharto, Membangun Masyarakat, Memberdayakan Rakyat; Kajian Strategis Pembangunan kesejahteraan Sosial dan pekerjaan Sosial, Bandung: PT. Refika Aditama, 2017

[33] Erick Namara, 101 Peluang Bisnis Sampingan Bagi Karyawan, Yogyakarta: Media Press, 2010

[34] Fadila Grine, Empowerment Muslim Women Though Executive Coaching and Mentoring Jurnal Internasional Nusantara Islam Vol.2 No.1 Tahun 2014

[35] Fadlullah, Pendidikan Entrepreneurship Berbasis Islam Dan Kearifan Lokal, Jakarta: Diadit Media Press, 2011

[36] Feti Fatimatuzahraoh, Oekan S. Abdoellah, dan Sunardi, The potential of pesantren in sustainable Rural Development, International Multidisciplinary Journal, Vol 3, No. 2 Mei 2015

[37] Fridreck Taylor, Scientifiq Management, Happer And Breos, New York, 1974

[38] Gareth R. Jones., Jennifer M. George., Essentials of Contemporary Management, New York: McGraw-hill

[39] George R. Terry, Prinsip-prinsip Manajemen. Jakarta: PT. Bumi Angkasa, 2008 
[40] George R.Terry, Asas-asas Manajemen, alih bahasa Dr. Winardi, Bandung: PT.Alumni, 2012

[41] Gunawan dan Ari Wulandari, Membangun Indonesia dari Desa. Yogyakarta: Media Pressindo, 2016

[42] Imam an-Nawawi, Riyadlu ash-sholikhin,. Jiddah: Daaru al-qiblah li ats- tsaqafah al Islamiyyah, 1990

[43] Imam Gunawan, Metode Penelitian Kualitatif: Teori \& Praktik, akarta: Bumi Aksara, 2013

[44] Heru Setiawan, Kompetensi Kewirausahaan Kepala Sekolah Dalam Menciptakan Kemandirian Sekolah Menengah Kejuruan Di Provinsi Jambi. Disertasi, UIN Sulthan Thaha Saifuddin Jambi Tahun 2018

[45] Herdi Salioso, Kota Dumai Pantai Timur Sumatera, Pekanbaru: UNRI Press, 2003

[46] Hendry Faizal Noor, Investasi, Pengelolaan Keuangan, dan Pengembangan Ekonomi Masyarakat, Jakarta: Mitra Wacana Media, 2014

[47] Indragiri Hulu dalam Angka 2014, BAPEDDA dan Litbang Kabupaten Indragiri Hulu, 2015

[48] Imam Bawani dkk, Pesantren Buruh Pabrik: Pemberdayaan Buruh Pabrik Berbasis Pendidikan Pesantren, Yogyakarta: LKis Yogyakarta, 2011

[49] Isnaen Wiardani, Budidaya Jamur Konsumsi, Menangguk Untung Dari Budidaya Jamur Tiram dan Jamur Kuping, Yogyakarta: Lily Publisher, 2010

[50] Jazim Hamidi dan Mustafa Lutfi, Entrepreneurship Kaum Sarungan, Jakarta: Khalifa, 2010

[51] Kasmir, Kewirausahaan. Jakarta: Rajawali Press, 2011

[52] Kaspul Anwar US, Kepemimpinan Pesantren; Menawarkan Model Kepemimpinan Kolektif dan Responsif, Jambi: Sulthan Thaha Press, 2011

[53] Kesi Widjajanti, Model Pemberdayaan Masyarakat, Jurnal Ekonomi Pembangunan,Volume 12, Nomor 1, Juni 2011

[54] Kaelan, Metodologi Penelitian Kualitatif Interdisipliner, Yogjakarta: Paradigma, 2012 Lukman Fauroni, Menggerakkan Ekonomi Syariah dari Pesantren, Yogyakarta: Forum Pengkajian Pendidikan dan Pesantren, 2017

[55] Masdar Hilmy, Pendidikan Islam Dan Tradisi Ilmiah, Malang: Madani, 2016.

[56] Muhammad Ali Anwar, Manajemen Kelembagaan Pondok Pesantren; Strategi dan Pengembangan Ditengah Modernisasi Pendidikan, Yogyakarta: Pustaka Ilmu, 2017

[57] Muhammad Anwar, Pengantar Kewirausahaan: Teori dan Aplikasi. Jakarta: Kencana, 2017

[58] M.Anton, Athoillah, Dasar-dasar Manajemen. Bandung: Pustaka Setia, 2017

[59] Made Dharmawati, Kewirausahaan, Jakarta: Rajawali Press, 2016

[60] M. Ridwan Nashir, Mencari Tipologi Format Pendidikan Ideal: Pondok Pesantren Ditengah Arus Perubahan, Yogyakarta: Pustaka Pelajar, 2010

[61] Matthew B. Miles \& A. Michael Huberman. Analisis Data Kualitatif, Jakarta: UI Press. 2009

[62] Maskuri Bakri, Pemberdayaan Masyarakat: Pendekatan RRA dan PRA. Surabaya: Visi Press Media, 2017

[63] Moh. Ali Aziz ed, Dakwah Pemberdayaan Masyarakat, Yogyakarta: PT. LKiS Pelangi Akasara, 2009

[64] Musa asy"earie, Dialektika Islam: Etos Kerja Dan Kemiskinan. Yogyakarta: LESFI, 2016

[65] Mark Casson, Alih bahasa Benri Sjah, Entrepreneuship: Teori, Jejaring, Sejarah, Jakarta: Rajawali Press, 2016

[66] Mukhtar, Metode Praktis Penelitian Deskriptif Kualitatif. Jakarta Selatan: Referensi GP. Press Group, 2013

[67] M. Bahri Gazali, Pesantren Berwawasan Lingkungan, Jakarta: Prasati, 2003

[68] Muhammad Rakib, Model Pemberdayaan Masyarakat, Dosen Fakultas Ekonomi Universitas Negeri Makassar Jurnal Administrasi Publik, Volume 6 No. 1 Thn. 2016

[69] Mohammad Nadzhir, Membangun Pemberdayaan Ekonomi di Pesantren, dalam Jurnal Economica, Volume VI/Edisi 1/Tahun 2015 
[70] Mohamad Mustari, Peranan Pesantren dalam Pembangunan PendidikanMasyarakat Desa, Yogyakarta: Multi Press, 2011.

[71] Mohamad Mustari, Ekonomi Pesantren, Bekasi, Lintang Publishing, 2012

[72] Monday, RW. Sharpin and Flippo, Management concept and practies, Boston: allyn and Bacon, 1988

[73] Muhammad Ridwan, Manajemen BMT, Yogyakarta: UII Press, 2014.

[74] Mujamil Qomar, Pesantren dari Transformasi Metodologi Menuju Demokratisasi Institusi, Jakarta: Erlangga, $t \mathrm{tt}$

[75] Nana Syaodih Sukmadinata. Metode Penelitian Pendidikan, Bandung: Remaja Rosda Karya, 2011

[76] Nana Herdiana Abdurahman, Manajemen Bisnis Syariah dan Kewirausahaan, Bandung: Pustaka Setia, 2013

[77] Nurul Huda, dkk, Ekonomi Makro Islam, Jakarta: Kencana, 2015

[78] Peter F. Druker, Inovation and Entrepreneurship, Canada, Harper Collin, tt Prasetyani dan Purusa, Studi Empiris Wirausaha Perempuan Di Surakarta; Factor-Faktor yang Mempengaruhi Motivasi, Hambatan dan Keberhasilan Usaha, Jurnal Penelitian Ekonomi dan Bisnis, 2016,

[79] Piryadi, Modul Pelatihan Budidaya Jamur Tiram, Jakarta: Agromedia Pustaka, 2019

[80] Profil Daerah Provinsi Riau tahun 2012: Badan Perencanaan Pembangunan Daerah Provinsi Riau Direktorat Jenderal Bina Pembangunan Daerah Kementerian Dalam Negeri.

[81] R L u k m a n Fauroni, Model Pemberdayaan Ekonomi Ala Pesantren Al-Ittifaq Rancabali Kabupaten Bandung, Jurnal Inferensi, Vol. 5, No. 1, Juni 2011

[82] Ramayulis dan Samsul Nizar, Filsafat Pendidikan Islam: Telaah Sistem Pendidikan dan Pemikiran Para Tokohnya, Kalam Mulia: Jakarta, 2009

[83] Rochmat Koswara, Manajemen Pelatihan Life Skill Dalam Upaya Pemberdayaan Santri Di Pondok Pesantren, Jurnal Empowerment, Vol. 04 No. 01 Februari 2014

[84] Ryan Yudistian, S.P. Budi Daya Jamur Tiram Putih Untuk Pemula Bandung: P.T Pribumi Mekar, 2016.

[85] Rizal Muttaqin, Kemandirian dan Pemberdayaan Ekonomi Berbasis Pesantren, Jurnal Ekonomi syariah Indonesia, Volume I, No.2 Desember 2011

[86] Riau Business Guide; Biro Administrasi Perekonomian Sekretariat Daerah Pemerintah Provinsi Riau, 2016

[87] Samsul Nizar, Sejarah Sosial Dan Dinamika Intelektual Pendidikan Islam Di Nusantara, Jakarta: Kencana, 2013

[88] Siswanto, Arnamu, Margono Setiawan dan Umar Nimran, Entrepreneurial Motivation in Pondok Pesantren Jurnal Internasional Journal of business dan ilmu perilaku Vol 3 No. 2 Februari 2013

[89] Syammahfuz Chazali dan Putri Sekar Pratiwi, Usaha Jamur Tiram Skala Rumahan, Yogyakarta: Gramedia, 2011

[90] Sudjana, Pendidikan Non-Formal, Bandung: Falah Production, 2014

[91] Soerjono Soekanto, Sosiologi Suatu Pengantar, Jakarta: Rajawali Press, 2012

[92] Sofia, Kontruksi Model Kewirausahaan Social (Social Entrepreneurship) Sebagai Gagasan Inovasi Social Bagi Pembangunan Perekonomian, Journal Pemberdayaan, 2015

[93] Sugiyono, Memahami Penelitian Kualitatif, Bandung: Alfabeta, 2008

[94] Suwardi dkk, Sejarah Perjuangan Rakyat Riau 1959-2002, Pekanbaru: Badan kesejahteraan Sosial Provinsi Riau, 2004

[95] Supriyanto, Pemberdayaan Ekonomi Komunitas Pesantren dalam Perspektif Pendidikan Ekonomi: (Studi Multi Situs di Pesantren Sidogiri dan Pesantren Paras Gempal Jawa Timur). Disertasi, Tahun 2011. Program Studi Pendidikan Ekonomi. UIN Malang

[96] Setyorini Pradiyati dkk, Pola Pemberdayaan Masyarakat melalui Pondok Pesantren, Jakarta: Ditjen kelembagaan Departemen Agama RI, 2003

[97] Sugiono, Metode Penelitian Pendidikan Pendekatan Kuantitatif, Kualitatif dan R\&D Bandung: Alfabet, 2012 
[98] Soetomo, Pembangunan Masyarakat, Yogyakarta: Pustaka Pelajar, 2012.

[99] Soetomo, Pemberdayaan Masyarakat, Yogyakarta: Pustaka Pelajar, 2018

[100] Stephen P. Robbins - Mary Coultr, Alih Bahasa Bob Sabran, Manajemen Jilid 2. Jakarta: Erlangga, 2016

[101] Totok Mardikanto dan Poerwoko Soebiato, Pemberdayaan Masyarakat Dalam Persfektif Publik, Bandung: Alfabeta, 2017

[102] T.Gilarso, Pengantar Ilmu Ekonomi Mikro, Yogyakarta: Kanisius, 2013 Undang-Undang No.18 Tahun 2019 tentang Pesantren.

[103] Unus Suriawiria, Budi Daya Jamur Tiram, Yogyakarta: Kanisius, 2011

[104] Valerie D. Squire-Kelly, The Relationship between Teacher empowerment and Student Achievement, Disertasi, Georgia Southern University: Tahun 2012.

[105] Wisnu Indrajit dan Soimin, Pemberdayaan Masyarakat dan Pembangunan, Malang: Intrans Publishing, 2014

[106] Yadi Janwari, Entrepreneurship of Traditionalists Muslim at Tasikmalaya, West Java, Internasional Journal of Islam Nusantara, Vol 1, No.1 tahun 2013 Entrepreneurship of Traditionalists Muslim at Tasikmalaya, West Java

[107] Yusuf dan Suwito, Model Pengembangan Ekonomi Pesantren, Purwekerto: STAIN Purwokerto Press, 2010

[108] Zainal Arifin, Manajemen Pengembangan Kurikulum Pendidikan Islam Yogyakarta: FKIP UIN Sunan Kalijaga Yogyakarta, 2011. 